Abstracta Iranica Abstracta Iranica

Revue bibliographique pour le domaine irano-aryen

Volume 22 | 2001

Comptes rendus des publications de 1999

\title{
Autobiographie d'un clerc chiite du Ğabal 'Āmil. Trad. et annot. par Sabrina Mervin et Haïtham Al-Amin, Damas, IFEAD, 1998, 217 p.
}

\section{Denise Aigle}

\section{(2) OpenEdition}

Journals

Édition électronique

URL : http://journals.openedition.org/abstractairanica/36637

DOI : 10.4000/abstractairanica.36637

ISSN : 1961-960X

Éditeur :

CNRS (UMR 7528 Mondes iraniens et indiens), Éditions de l'IFRI

\section{Édition imprimée}

Date de publication : 15 mai 2001

ISSN : 0240-8910

Référence électronique

Denise Aigle, «Autobiographie d'un clerc chiite du Ğabal 'Āmil. Trad. et annot. par Sabrina Mervin et Haïtham Al-Amin, Damas, IFEAD, 1998, 217 p. », Abstracta Iranica [En ligne], Volume 22 | 2001, document 268, mis en ligne le 15 février 2010, consulté le 13 octobre 2020. URL : http:// journals.openedition.org/abstractairanica/36637 ; DOI : https://doi.org/10.4000/abstractairanica 36637

Ce document a été généré automatiquement le 13 octobre 2020

Tous droits réservés 


\title{
Autobiographie d'un clerc chiite du Ğabal 'Āmil. Trad. et annot. par Sabrina Mervin et Haïtham Al-Amin, Damas, IFEAD, 1998, 217 p.
}

\author{
Denise Aigle
}

1 Né à Šaqaāā, un village du Jabal 'Āmil, Muhsin al-Aminn s'installa à Damas en 1901 où il s'imposa comme le chef spirituel de la communauté chiite. Ce récit de vie, extrait de son dictionnaire biographique A'yān al-Šš $a$, retrace le parcours du savant (édition du texte arabe sous le titre Sirrat al-Sayyid Muhsin al-Amin, éd. Haythâm al-Amîn et Sabrina Mervin, Beyrouth, Riad El-Rayyes Books, 2000, 221 p.). Le texte, ici traduit, nous plonge dans l'univers d'un clerc chiite.

2 Ce récit de vie est très vivant et fourmille d'anecdotes sur la vie quotidienne. La description des études à Najaf (pp. 108-112) retiendra ici l'attention du spécialiste de l'Iran. Le cycle des cours s'organisait selon deux niveaux. Le premier cycle «les niveaux » (al-suțūh) était dispensé dans le domaine de la syntaxe, de la morphologie, de la rhétorique, de la logique et dans celui des ușūl, du fiqh et de la théologie. Cet enseignement s'appuyait sur l'étude des « livres », lus et commentés par le maître. En revanche, le second cycle (al-Hārij) s'effectuait « hors les livres » car il ne s'appuyait sur aucun ouvrage. Ce cycle, centré sur les uṣūl et le fiqh, menait à l'ijtihād. Nous soulignerons que Muḥsin al-Amīn suivit à Najaf l'enseignement de plusieurs maîtres venus d'Iran: Mullā Kāẓim al-Hูurāsānī, Āèā Riḍā al-Hamadānī, 'Abd-Allāh alMāzandārānī, Sayyid Kāẓim al-Yazdī, Mīrzā Ḥabīb-Allāh al-Raštī, Mīrzā Ḥusayn b. Mīrzā Hyalì al-Tihrānī (voir la biographie de ce dernier pp.127-128). Plusieurs anecdotes illustrent bien le fait que Najaf était un centre de savoir religieux où l'influence persane était très forte: les savants pouvaient communiquer entre eux en persan (exemple p. 138, bekešid). En 1933, Muḥsin al-Amīn passa onze mois à visiter les lieux saints d'Irak et d'Iran dont il dit avoir gardé un excellent souvenir : «Je remercie Dieu pour tout ce qui m'est arrivé en Irak et en Iran » (p. 176). 
3 La traduction du texte est précédée d'une présentation (pp.9-32) de Muhsin al-Amīn comme savant réformiste chiite. La question du genre «autobiographie » dans le monde musulman est abordée en présentant les recherches récentes en la matière et en mentionnant quelques récits de vie traduits et commentés (pp. 16-19).

INDEX

Thèmes : 4.3. Histoire de l'Iran moderne (à partir de 1905)

\section{AUTEURS}

DENISE AIGLE

EPHE - Paris 